\title{
Antioxidant Effects of Alperujo Extract (Arbequina and Frantoio Varieties) on MIN6 $\beta$-Cells Subjected to Stress with Glucose or $\mathrm{H}_{2} \mathrm{O}_{2}$
}

\author{
César González ${ }^{1}$, Mónica Andrews ${ }^{2}$, Elba Leiva ${ }^{1}$, Cristina Quispe $^{3}$, Miguel Arredondo ${ }^{*}$ \\ ${ }^{1}$ Faculty of Health Sciences, University of Talca, Interdisciplinary Research Program on Healthy Aging (PIEI-ES), \\ Talca, Chile \\ ${ }^{2}$ Micronutrient Laboratory, Institute of Nutrition and Food Technology (INTA), University of Chile, Santiago, \\ Chile \\ ${ }^{3}$ Institute of Chemistry of Natural Resources, University of Talca, Talca, Chile \\ Email: ${ }^{\text {marredon@inta.uchile.cl }}$
}

Received 30 April 2014; revised 3 June 2014; accepted 15 June 2014

Copyright (C) 2014 by authors and Scientific Research Publishing Inc.

This work is licensed under the Creative Commons Attribution International License (CC BY). http://creativecommons.org/licenses/by/4.0/

(c) $\underset{\mathrm{EY}}{\mathrm{P}}$ Open Access

\begin{abstract}
Alperujo, an antioxidant-rich by-product of olive oil extraction, could protect $\beta$-cells against oxidative damage. Our goal was to study the antioxidant effects of an alperujo extract (AE) on MIN6 $\beta$-cells challenged with glucose or hydrogen peroxide. MIN6 $\beta$-cells were challenged with glucose $(100 \mathrm{mM})$ or $\mathrm{H}_{2} \mathrm{O}_{2}(0.15 \mathrm{mM})$, with or without $\mathrm{AE}(20 \mu \mathrm{M}$ phenol). Reactive oxygen species, intracellular iron (Fe), insulin, glucose uptake, and mRNA gene expression of Uncoupling Protein-2 (UCP-2), Thioredoxin (TRDX), p47phox, and the ratio Bax/Bcl-2 were measured. ROS increased when the stressors were incubated with $\mathrm{AE}$ ( $\mathrm{p}<0.05$ and $\mathrm{p}<0.01$, respectively). Intracellular Fe increased in glucose presence $(100 \mathrm{mM} p<0.001)$. Insulin secretion improved when cells were pre-incubated with AE $(p<0.001)$ and glucose uptake increased when cells were pre-incubated with $\mathrm{AE}$ for 3 days and then further treated with glucose $(\mathrm{p}<0.001)$. After 3 days of $\mathrm{AE}$ alone, mRNA relative expression of UCP-2 and TRDX increased $(p<0.001)$ and after 5 days $p 47 \mathrm{phox}$, also increased. The Bax/Bcl-2 ratio tended to decrease in the samples pre-incubated with AE. The Alperujo extract, in vitro, had a pro-oxidant behavior, however pre-incubating MIN6 $\beta$-cells with AE tended to protect them against apoptosis, thereby enhancing insulin secretion.
\end{abstract}

\section{Keywords}

Alperujo, Oxidative Stress, Apoptosis, Glucose, $\beta$-Cells

\footnotetext{
${ }^{*}$ Corresponding author.
}

How to cite this paper: González, C., Andrews, M., Leiva, E., Quispe, C. and Arredondo, M. (2014) Antioxidant Effects of Alperujo Extract (Arbequina and Frantoio Varieties) on MIN6 B-Cells Subjected to Stress with Glucose or $\mathrm{H}_{2} \mathrm{O}_{2}$. Food and Nutrition Sciences, 5, 1280-1289. http://dx.doi.org/10.4236/fns.2014.513139 


\section{Introduction}

Olives and olive oil are nutritionally valuable parts of a diet, since the consumption of olives and olive oil is associated with a variety of health benefits, such as lower incidences of heart disease and certain types of cancer [1]-[4]. These findings have prompted a considerable amount of research into the composition of olive fruits, and nature of those components responsible for the observed beneficial health effects [4].

The olive oil industry produces large amounts and varieties of waste that are rich in phenol compounds [5]. HPLC analyses of olive oil extracts indicate that hydroxyl-tyrosol and p-tyrosol were the most abundant phenolic compounds; among these extracts alperujo has the highest concentration in hydroxyl-tyrosol and antioxidant activity [6]. Alperujo, potentially a natural source of antioxidant, may therefore protect an organism against damage caused by oxidative agents involved in the etiology of chronic diseases such as diabetes [7]-[12].

A central component to the development of type-2 diabetes mellitus is the progressive failure of pancreatic islet $\beta$-cells [13] [14]. Pancreatic $\beta$-cells secrete insulin to regulate blood glucose homeostasis. In the pancreas, glucose is transported into $\beta$-cells using glucose transporter type-2 (GLUT-2), and is subsequently oxidized by glycolytic pathways, the tri-carboxylic acid cycle, and mitochondrial oxidative phosphorylation [15]-[17]. Electrons that are derived from glucose metabolism move down the electron-transport chain, producing ATP through ATP synthase. ATP facilitates the release of insulin from pancreatic $\beta$-cells. Under glucotoxic conditions, mitochondrial superoxide production is elevated, resulting from an increased donation of electrons to the electron transport chain in addition to an increase in protons pumped out of the mitochondrial matrix [17]-[19]. These events activate mitochondrial uncoupling protein 2 (UCP-2), which is not normally highly expressed in $\beta$-cells, whose physiological function is to protect the cell against reactive oxygen species (ROS). However, its protective function results in a $\beta$-cell dysfunction because it negatively regulates insulin secretion [14] [17].

When oxidative stress induced by high metabolic loads exceeds the repair mechanism of the cell, oxidized molecules accumulate and compromise mitochondrial membrane integrity, releasing cytochrome c into the cytosol, thereby inducing apoptosis [20].

As in other cells types, the mitochondrial respiratory chains represent a major source of ROS in $\beta$-cells [21] However, NADPH oxidases are another source of ROS associated with the plasma membrane. These enzymes catalyze the NADPH-dependent cytosolic reduction of molecular oxygen (O2) to superoxide. Superoxide is converted spontaneously, converted through manganese superoxide dismutase (Mn-SOD) activity in the mitochondria or through copper-zinc superoxide dismutase (Cu/Zn-SOD) in the cytosol, to peroxide hydrogen $\left(\mathrm{H}_{2} \mathrm{O}_{2}\right)$ [22]. $\mathrm{H}_{2} \mathrm{O}_{2}$ can be removed by either catalase (CAT) or peroxidases. CAT catalyzes direct decomposition of $\mathrm{H}_{2} \mathrm{O}_{2}$ to $\mathrm{O}_{2}$ and water. In contrast, glutathione peroxidase (GSH-Px) removes $\mathrm{H}_{2} \mathrm{O}_{2}$ using glutathione (GSH) oxidation coupling. Thioredoxin peroxidase, or peroxiredoxin, removes $\mathrm{H}_{2} \mathrm{O}_{2}$ through thioredoxin (TRDX) oxidation coupling, a widely distributed polypeptide containing 2 thiol groups. Thioredoxin peroxidase catalyzes $\mathrm{H}_{2} \mathrm{O}_{2}$ more slowly, but is more abundant than glutathione peroxidase in most tissues [22].

Since $\beta$-cells have a low antioxidant defense capacity, they are very sensitive to ROS-induced stress associated with an increase in glucose metabolism. Therefore, protecting $\beta$-cells against oxidative stress is important in preventing diabetes, and natural antioxidants could be useful in this endeavor. Our aim was to investigate the anti-oxidative effects, in vitro, of an aqueous alperujo extract on ROS production and MIN6 $\beta$-cell function subjected to stress with glucose and $\mathrm{H}_{2} \mathrm{O}_{2}$.

\section{Materials and Methods}

\subsection{Phenolic Extraction from Alperujo and HPLC Analysis}

A mixture of aqueous AE (kindly provided by the Chemistry Institute of Natural Resources, University of Talca, Talca, Chile) from Arbequina and Frantoio varieties was used. Alperujo extract (100 mg) was re-dissolved in 1 $\mathrm{mL}$ of methanol: water (1:1), then sonicated for $30 \mathrm{~min}$ (ultrasound-sonicator, Elma, BioLogicsInc, Virginia, USA). $50 \mu \mathrm{l}$ of each calibrator (Tyrosol (2-(4-Hydroxy-phenyl) ethanol) and Trihydroxityrosol (3-Hydroxytyrosol); Sigma Aldrich Co.), controls and samples were mixed with $50 \mu \mathrm{l}$ of internal standard (Primidone, $20 \mu \mathrm{g} / \mathrm{mL}$ in methanol, Laboratorio Chile S.A, Chile). Each sample was vortexed for $10 \mathrm{~s}$ and impregnated on a roll cellulose (Whatman filter paper $3.5 \times 7 \mathrm{~cm}$ ) that was contained in a $5 \mathrm{~mL}$ glass tube. Then, $1 \mathrm{~mL}$ of ethyl acetate was added to each tube and vortexed for $10 \mathrm{~s}$. This step was repeated until complete $3 \mathrm{ml}$ of ethyl acetate and then was evaporated at $40^{\circ} \mathrm{C}$ to dryness [23].

HPLC analysis was performed using a HPLC/UV Agilent 1100 (Agilent Technologies, CA, USA). Separation 
of Phenolic compounds were performed on a Zorbax XDB C18 $(4.6 \times 30 \mathrm{~mm}$; 3.5 um particle size, Agilent Technologies, CA, USA). All analysis were performed using an isocratic mobile phase (water: methanol: acetonitrile, 70:24:6; $\mathrm{pH} 7.0$ ). The dry residue was re-dissolved in $75 \mu \mathrm{l}$ of mobile phase. The injection volume was $10 \mu \mathrm{l}$ at a flow rate of $1 \mathrm{~mL} / \mathrm{min}$. The UV absorbance of the eluent was measured at $280 \mathrm{~nm}$. Phenolic concentrations were calculated by linear last-squares regression analysis of calibration curves of each compound, using height ratio between sample and internal standard. The main polyphenols in the mix were: 3.66 and $2.54 \mu \mathrm{g}$ Hydroxytyrosol/mg alperujo Arbequina and Frantoio varieties, respectively; and $0.230 \mu \mathrm{g}$ Tyrosol/mg alperujo Arbequina. The alperujo extract containing $0.5 \mathrm{~g} / 100 \mathrm{~mL}$ of gallic acid equivalents or phenol, measured by the Folin-Ciocalteau method [24] was used.

\subsection{Cell Culture}

Pancreatic $\beta$-cell line MIN6 (kindly donated by the Cellular Communication Laboratory, Faculty of Medicine, University of Chile, Santiago, Chile) was cultured in DMEM containing $25 \mathrm{mM}$ glucose; $10 \%$ fetal bovine serum (FBS); streptomycin $(100 \mu \mathrm{g} / \mathrm{mL})$; and penicillin $(100 \mathrm{IU} / \mathrm{mL})$ at $37^{\circ} \mathrm{C}$ under a humidified atmosphere containing 5\% $\mathrm{CO}_{2}$. Treatments were performed over 5 days as follow: 1) Control: cells cultured with neither AE nor stressors; 2) EA 3d: cells cultured without glucose or $\mathrm{H}_{2} \mathrm{O}_{2}$ and challenged with AE during the last three days of incubation; 3) EA 5d: cells cultured with neither glucose nor $\mathrm{H}_{2} \mathrm{O}_{2}$ and challenged with $\mathrm{AE}$ from the first day of incubation; 4) Glucose: cells cultured with glucose and without AE; 5) Glucose/EA 3d: cells cultured with glucose and challenged with AE during the last three days of incubation; 6) Glucose/EA 5d: cells cultured with glucose and challenged with $\mathrm{AE}$ from the first day of incubation; 7) EA/Glucose 2d: cells cultured with AE from the first day of incubation and challenged with glucose during the last two days of incubation; 8) $\mathrm{H}_{2} \mathrm{O}_{2}$ : cells cultured with $\mathrm{H}_{2} \mathrm{O}_{2}$ and without AE; 9) $\mathrm{H}_{2} \mathrm{O}_{2}$ /EA 3d: cells cultured with $\mathrm{H}_{2} \mathrm{O}_{2}$ and challenged with $\mathrm{AE}$ during the last three days of incubation; 10) $\mathrm{H}_{2} \mathrm{O}_{2}$ /EA 5d: cells cultured with $\mathrm{H}_{2} \mathrm{O}_{2}$ and challenged with $\mathrm{AE}$ from the first day of incubation; 11) EA/H2O2 2d: cells cultured with $\mathrm{AE}$ from the first day of incubation and challenged with $\mathrm{H}_{2} \mathrm{O}_{2}$ the last two days of incubation. For all of the conditions, on the last day of incubation, RNA was isolated, protein extract was prepared and it was determined glucose-H3 uptake. For intracellular ROS measurement, similar incubation conditions were done, but in a $24 \mathrm{~h}$ period where the pre-treatment with AE was for 12 hours, whereupon the stressors were added.

\subsection{MTT Assay}

MIN6 $\beta$-cells $(5 \times 104$ cells $/ 10 \mu \mathrm{L})$ were seeded in 96-well plates with glucose $(100-180 \mathrm{mM}), \mathrm{H}_{2} \mathrm{O}_{2}(0.035$ $0.25 \mathrm{mM})$, and AE (20 - $300 \mu \mathrm{M}$ total phenol) concentrations for $24 \mathrm{~h}$. The MTT assay was performed as follows: the culture medium was removed, and $100 \mu \mathrm{L}$ of fresh DMEM was added along with $10 \mu \mathrm{L}$ of MTT (12 $\mathrm{mM})$. After incubating for 4 hours with $\mathrm{MTT}$ at $37^{\circ} \mathrm{C}$, solubilization buffer $(100 \mu \mathrm{L} ; 10 \%$ SDS in $0.01 \mathrm{M} \mathrm{HCl})$ was added. The absorbance was measured with the SpectraMax M5 Multi-Mode Microplate Readers (Molecular Devices, California, USA) at $570 \mathrm{~nm}$.

\subsection{Reverse Transcription and Real-Time PCR}

Total RNA was extracted using TRIzol ${ }^{\circledR}$ LS Reagent (Invitrogen, USA). Total RNA concentration and purity were determined by measuring the absorbance at 260/280 nm (Biochrom WPA Biowave DNA, Life Science Spectrophotometer). The samples were treated with DNAse (TURBO DNA-free ${ }^{\mathrm{TM}} \mathrm{kit}$, Invitrogen, USA) to avoid contamination and parallel amplification. RT-PCR was performed using total RNA $(1.5 \mu \mathrm{g} / \mu \mathrm{l})$ with a High Capacity cDNA Reverse Transcription Kit (Applied Biosystems, USA). For qPCR analysis, synthesized cDNA was added to a PCR mixture containing DNA polymerase of the primers, beta-2 microglobulin (B2M) was used as housekeeping, the list of primers is available upon request. qPCR was conducted with $10 \mu \mathrm{L}$ of reaction mixture, containing Fast SYBR ${ }^{\circledR}$ Green Master Mix (Applied Biosystems, USA), using a real time PCR system (StepOne, Applied Biosystems, USA). Levels of mRNA relative expression were determined according to the mathematical model proposed by Pfaffl [25].

\subsection{Intracellular Iron Content}

Min-6 cells $(8 \times 105)$ were seeded in a six wells plate with the challenged as we mentioned previously. The cells 
were detached with Tris-EDTA solution and centrifuged to $900 \mathrm{~g}$ finally the pellet was resuspended in nitric acid $(70 \%)$ and lysate overnight at $70^{\circ} \mathrm{C}$. The intracellular iron (Fe) content was determined using an atomic absorption spectrometer (AAS) equipped with graphite furnace (SIMAA 6100, Perkin Elmer, Shelton, CT). MR-CCHEN-002 (Venus antiqua) and DOlt-2 (Dogfish liver) preparations were used as reference materials to validate the mineral analyses.

\subsection{Insulin Levels and Intracellular ROS Production Determination}

Insulin released was measured by RIA using a Coat-A-Count Insulin Kit (Siemens, USA) following the instructions of the manufacturer. Intracellular ROS production was evaluated using a cell-permeable fluorogenic probe 2',7'-Dichlorodihydrofluorescin diacetate (DCFH-DA) with a commercial kit (OxiSelect ${ }^{\mathrm{TM}}$ Intracellular ROS Assay kit (Green Fluorescence), Cell Biolabs INC, USA), following the instructions of the manufacturer.

\subsection{Radiometric Glucose Uptake Assay}

This assay was performed according to the proposal of Yamamoto et al., (2011) [26], using 3-O-(3H-Metyl)D-glucose (3MG) (Sigma Aldrich, USA). MIN-6 cells were seeded in a six-well plate $(8 \times 105$ cells/well). For all conditions, on the last day of incubation the culture medium was eliminated and replaced by $1 \mathrm{~mL}$ of $0.7 \mu \mathrm{M}$ $3 \mathrm{MG}$ dissolved in KRH buffer (Krebs-Ringer-HEPES). Cells were incubated for $1 \mathrm{~h}$ at $37^{\circ} \mathrm{C}$ and then washed with cold PBS. Cellular suspensions were centrifuged for $2 \mathrm{~min}$ at 13,000 $\times \mathrm{g}$. The pellets were treated with 100 $\mu \mathrm{L}$ of $\mathrm{Na}_{2} \mathrm{CO}_{3} 2 \% / \mathrm{NaOH} 0.1 \mathrm{~N}$ plus $1.2 \mathrm{~mL}$ of liquid scintillation, and vortexed. Radioactivity was measured in a liquid scintillation analyzer (Packard 1600 TR, Canberra Company).

\subsection{Statistical Analysis}

Each assay was performed in triplicate at least three times. Cell viability assay results are expressed as percentage of viability with respect to untreated control cells (mean $\pm \mathrm{SD}$ ). Glucose uptake (mM glucose-3H/mg protein) expressed fold changes compared to control cells (mean $\pm \mathrm{SD}$ ). The ROS production (fluorescence emitted); intracellular iron ( $\mu \mathrm{g}$ iron/mg protein); and insulin ( $\mu \mathrm{UI}$ insulin/ $\mu \mathrm{g}$ protein) values were expressed as mean \pm SD. mRNA relative expressions (mean \pm SEM) expressed fold changes with respect to the control condition. ANOVA was used to compare between different groups. Dunnett's post hoc test was used to compare each condition against the control group. $\mathrm{P}<0.05$ was statistically significant. The data were analyzed using computational software (GraphPad Prism $\left.{ }^{\circledR}\right)$.

\section{Results}

\subsection{MIN6 $\beta$-Cell Viability under Different Concentrations of $\mathrm{H}_{2} \mathrm{O}_{2}$, Glucose, and Phenol from $\mathrm{AE}$}

Figure 1 shows that cell viability decreased when the $\mathrm{H}_{2} \mathrm{O}_{2}$ concentration was increased, decreasing significantly $0.15 \mathrm{mM}$ of $\mathrm{H}_{2} \mathrm{O}_{2}$ (Figure 1 (a), one way ANOVA, p $<0.001$ ). For glucose, cell viability decreased $28 \%$ with $150 \mathrm{mM}$ glucose, and 68\% with 175 and $180 \mathrm{mM}$ glucose (one way ANOVA, $\mathrm{p}<0.01$ and 0.001 , respectively). MIN6 $\beta$-cell viability decreased at $100 \mu \mathrm{M}$ AE (Figure 1 (c), one way ANOVA, $\mathrm{p}<0.001$ ), but at higher concentrations, cell viability increased (one way ANOVA, $\mathrm{p}<0.001$ ). Since the following experiments required the cells to remain viable for a 5 day challenge, and MIN6 Beta-cells have only survived at a $100 \mathrm{mM}$ glucose (data not shown) concentration, $100 \mathrm{mM}$ of glucose was used as the stressor agent in the next experiments.

\subsection{ROS Production and Intracellular Iron in MIN6 $\beta$-Cell}

Glucose and $\mathrm{H}_{2} \mathrm{O}_{2}$ did not induce changes in intracellular ROS production compared to the control (Figure 2); however, ROS production increased from control levels in cultures containing AE. (One way ANOVA: AE = p $<0.05$; glucose $/ \mathrm{AE}=\mathrm{p}<0.01$ and $\mathrm{AE} / \mathrm{H}_{2} \mathrm{O}_{2}=\mathrm{p}<0.001$ ). In control cells, the total intracellular Fe concentration was $1.5 \mathrm{mg} \mathrm{Fe} / \mathrm{mg}$ protein. This concentration increased in cells incubated for 5 days with $100 \mathrm{mM}$ glucose and with AE (Figure 3, one way ANOVA, $\mathrm{p}<0.001$ and $\mathrm{p}<0.05$, respectively). Glucose challenged cells mostly favored an increase of intracellular Fe (3.9 vs. $2.5 \mathrm{mg}$ Fe/mg protein, one way ANOVA, p < 0.001). 


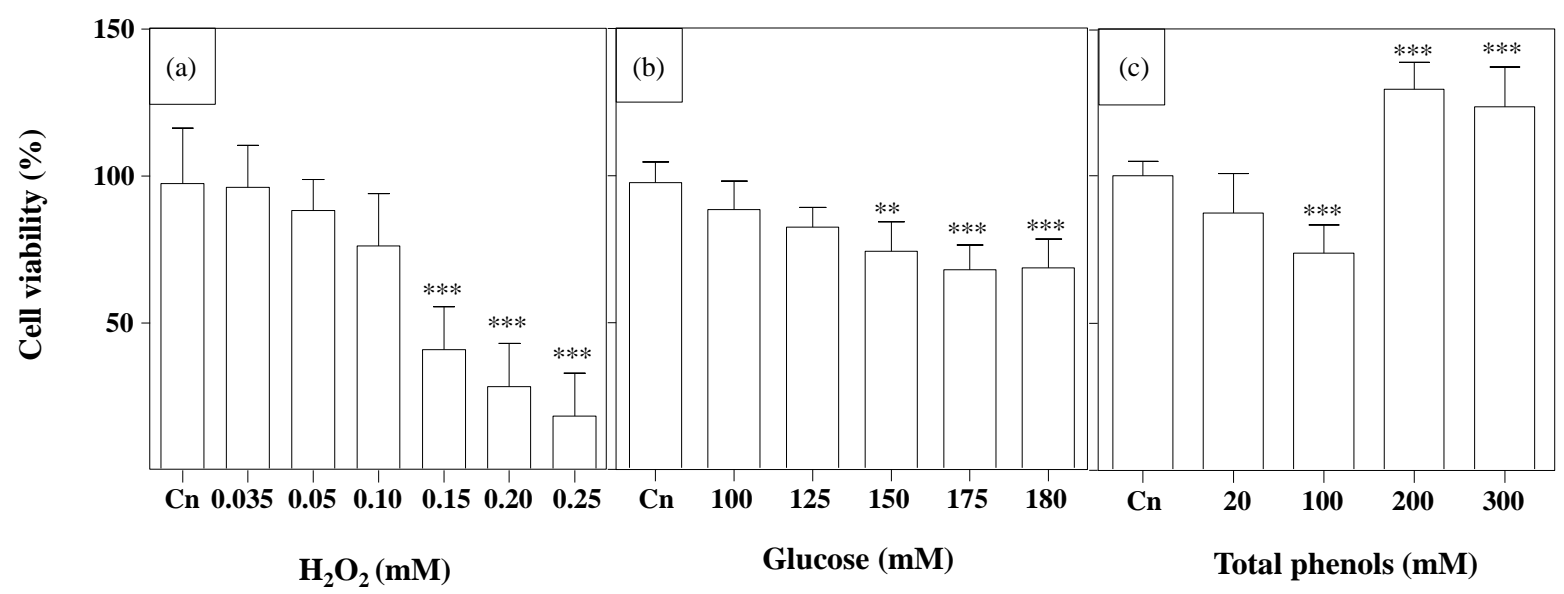

Figure 1. Cellular viability percentage with respect to MIN6 $\beta$-cell controls, exposed for 24 hours to different concentrations of (a) $\mathrm{H}_{2} \mathrm{O}_{2}$, (b) Glucose, (c) phenols from AE. Results are shown as mean \pm SD. One-way ANOVA, Dunnett's post hoc test: p $<0.01 ; \stackrel{* * *}{p}<0.001$.

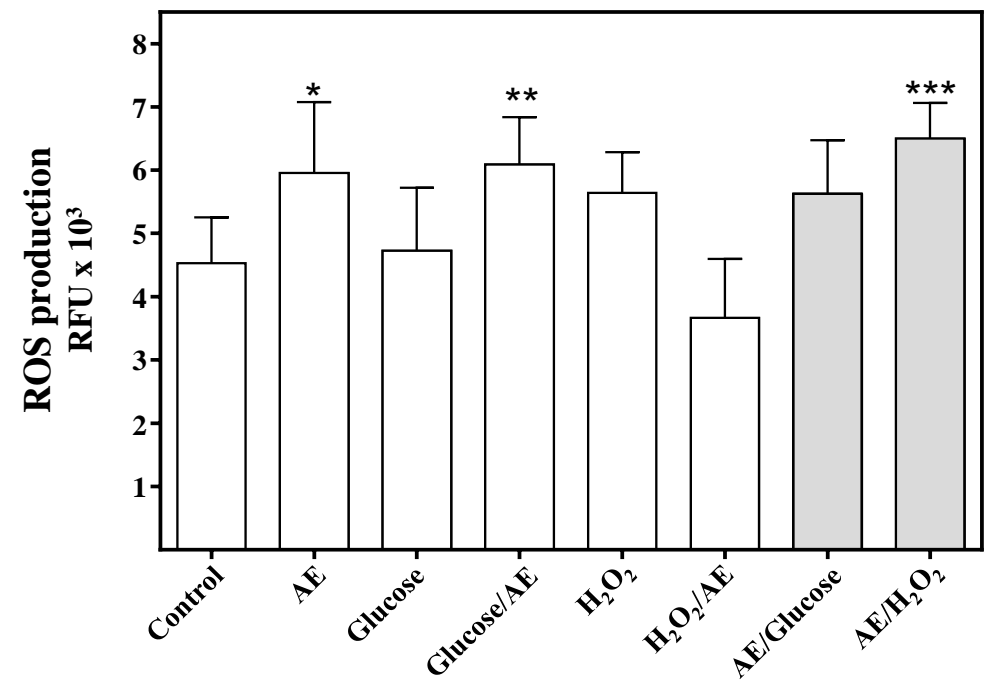

Figure 2. ROS production (relative fluorescence units, RFU) in MIN6 $\beta$ cells challenged with different treatments for 24 hours (white bars): Control; AE $\left(20 \mu \mathrm{M}\right.$ phenol); Glucose $(100 \mathrm{mM})$, Glucose/AE, $\mathrm{H}_{2} \mathrm{O}_{2}(0.15 \mathrm{mM})$; $\mathrm{H}_{2} \mathrm{O}_{2}$ /AE or pre-incubation for 12 hours with $\mathrm{AE}$ and subsequent incubation for 12 hours with the mixtures (Grey bars): $\mathrm{AE} /$ Glucose and, $\mathrm{AE} / \mathrm{H}_{2} \mathrm{O}_{2}$ : Results are shown as mean \pm SD. One-way ANOVA, Dunnett's post hoc test: ${ }^{*} \mathrm{p}<0.05 ;{ }^{* *} \mathrm{p}<0.01 ;{ }^{* * *} \mathrm{p}<0.001$.

Pre-incubation with $100 \mathrm{mM}$ of glucose and further treatment with $\mathrm{AE}$ for 3 days yielded an increase of intracellular Fe (Figure 3, one way ANOVA, $\mathrm{p}<0.001$ ). Pre-incubation with $\mathrm{H}_{2} \mathrm{O}_{2}$ did not change the intracellular Fe concentration. Pre-incubating the cells with AE for 3 days and then treating them with glucose and $\mathrm{H}_{2} \mathrm{O}_{2}$ produced a synergic effect (one way ANOVA, $\mathrm{p}<0.001$ ).

\subsection{Insulin Secretion and H3-Glucose Uptake in MIN6 $\beta$-Cells}

Cells challenged with glucose or $\mathrm{H}_{2} \mathrm{O}_{2}$ did not show any difference in insulin secretion, except in cells preincubated with $\mathrm{AE}$ and further treated with stressors (Figure 4(a), one way ANOVA, $\mathrm{p}<0.001$ ). Pre-incubation with $\mathrm{AE}$ and further treatments with glucose showed a higher insulin secretion than $\mathrm{H}_{2} \mathrm{O}_{2}$ (one way ANOVA, $\mathrm{p}$ $<0.01$ ). H3-glucose uptake increased in cells whose treatment included pre-incubation with AE for 3 days and then further treatment with glucose (Figure 4(b), one way ANOVA, $\mathrm{p}<0.001$ ). 


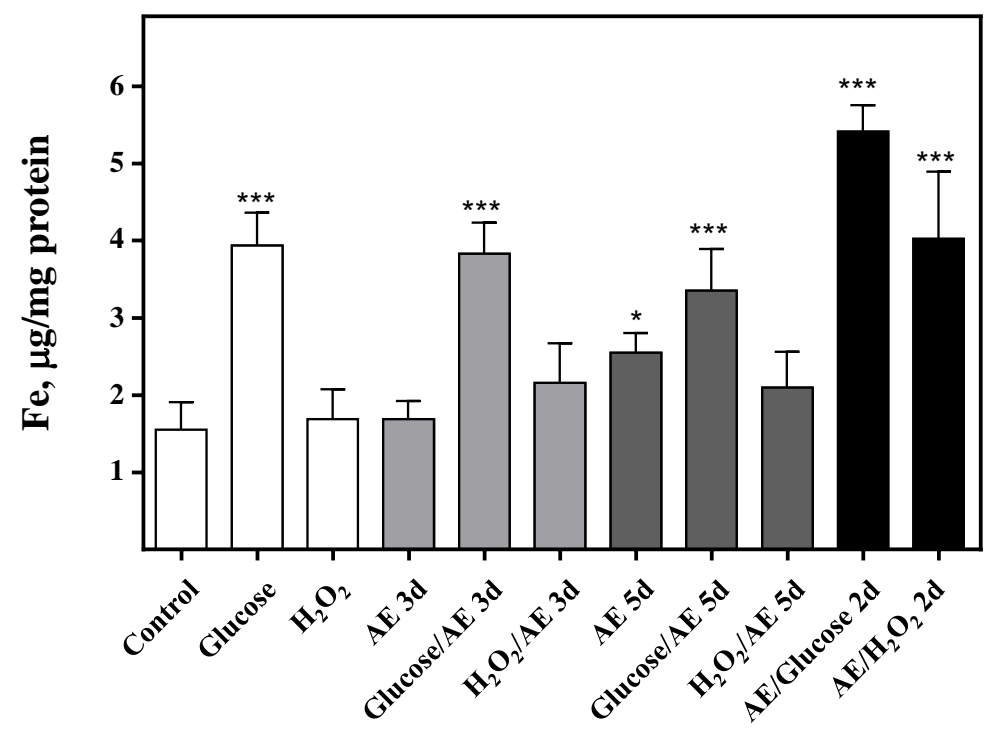

Figure 3. Intracellular iron concentration in MIN6 $\beta$-cells challenged with different treatments. The cellular assays were performed after day 5 (white bars): Controls; Glucose $(100 \mathrm{mM})$ or $\mathrm{H}_{2} \mathrm{O}_{2}(0.15 \mathrm{mM})$. The AE $(20 \mu \mathrm{M}$ phenol) was added 1) during the last 3 days of incubation (AE 3d; Grey bars)); 2) all 5 days of incubation (AE 5 d Grey dark bars); 3) for a 3-day pre-incubation prior to subsequent 2-day incubations with the mixtures (2d; Black bars). Results shown are mean \pm SD. One-way ANOVA, Dunnett's post hoc test: ${ }^{*} \mathrm{p}<0.05,{ }^{* * *} \mathrm{p}<0.001$.

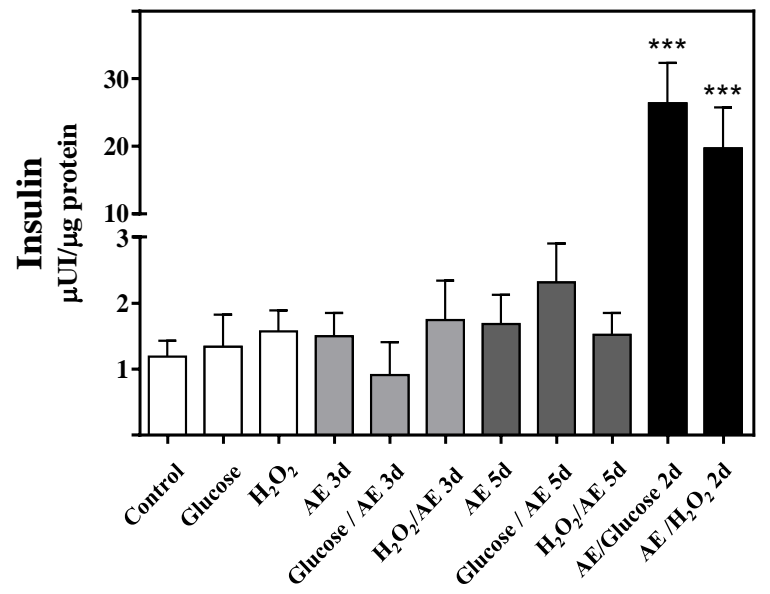

(a)

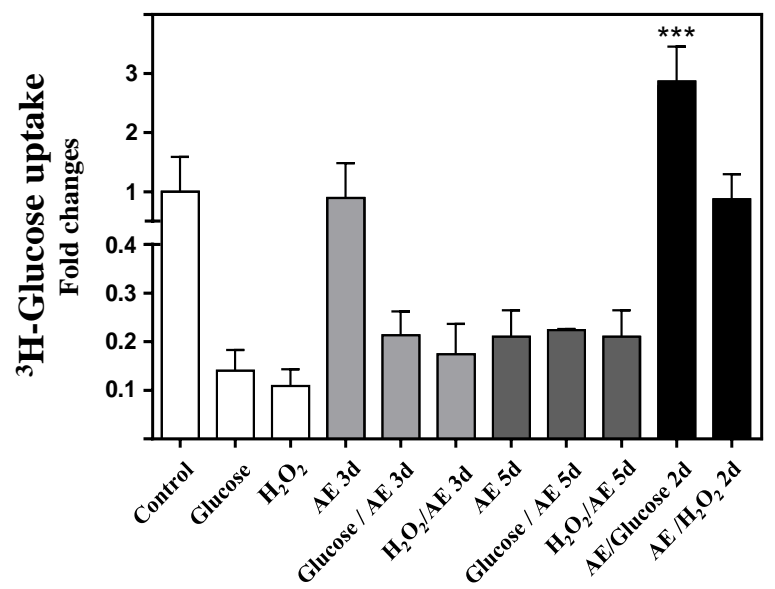

(b)

Figure 4. Insulin secretion (a) and 3H-Glucose uptake (b) from MIN6 $\beta$-cells challenged with different treatments. The cellular assays were performed after day 5 (white bars): Controls; Glucose $(100 \mathrm{mM})$ or $\mathrm{H}_{2} \mathrm{O}_{2}(0.15 \mathrm{mM})$. The $\mathrm{AE}(20 \mu \mathrm{M}$ phenol) was added 1) during the last 3 days of incubation (AE 3d; Grey bars)); 2) all 5 days of incubation (AE 5 d Grey dark bars); 3) for a 3-day pre-incubation prior to subsequent 2-day incubations with the mixtures (2d; Black bars). Results shown are mean \pm SD. One-way ANOVA, Dunnett's post hoc test: ${ }^{* * *} \mathrm{p}<0.001$.

\section{4. mRNA Relative Abundance of UCP-2, TRDX, p47phox, and Bax/Bcl-2 Ratio in MIN6 $\beta$-Cell}

Glucose and $\mathrm{H}_{2} \mathrm{O}_{2}$ without AE did not change UCP-2 mRNA abundance. However, the gene expression was increased in cells treated with AE for 3 days without glucose or $\mathrm{H}_{2} \mathrm{O}_{2}$ (Table 1 , one way ANOVA, p $<0.001$ ). The opposite effect was observed in cells treated with glucose and AE for 3 days (one way ANOVA, p $<0.001$ ). 
Table 1. mRNA relative abundance in MIN-6 $\beta$ cells challenge with glucose, $\mathrm{H}_{2} \mathrm{O}_{2}$ or Alperujo extract for different period of time.

\begin{tabular}{cccccccccccc}
\hline \multirow{2}{*}{ Gen } & \multirow{2}{*}{$\mathrm{Cn}$} & $\mathrm{G}$ & $\mathrm{H}_{2} \mathrm{O}_{2}$ & $\mathrm{AE}$ & $\mathrm{G} / \mathrm{AE}$ & $\mathrm{H}_{2} \mathrm{O}_{2} / \mathrm{AE}$ & $\mathrm{AE}$ & $\mathrm{G} / \mathrm{AE}$ & $\mathrm{H}_{2} \mathrm{O}_{2} / \mathrm{AE}$ & $\mathrm{AE} / \mathrm{G}$ & $\mathrm{AE} / \mathrm{H}_{2} \mathrm{O}_{2}$ \\
& & & & $3 \mathrm{ds}$ & $3 \mathrm{ds}$ & $5 \mathrm{ds}$ & $5 \mathrm{ds}$ & $5 \mathrm{ds}$ & $2 \mathrm{ds}$ & $2 \mathrm{ds}$ \\
\hline P47 & $2.6 \pm 0.2$ & $4.5 \pm 0.5$ & $3.1 \pm 1.5$ & $3.9 \pm 1.2^{* * *}$ & $6.8 \pm 0.5$ & $0.2 \pm 0.1$ & $18.4 \pm 1.5^{* * *}$ & $1.5 \pm 0.9$ & $2.7 \pm 1.0$ & $0.3 \pm 0.1$ & $0.4 \pm 0.2$ \\
TRDX & $2.3 \pm 0.9$ & $3.3 \pm 0.5$ & $1.1 \pm 0.7$ & $10.8 \pm 0.9^{* * *}$ & $3.3 \pm 0.2$ & $0.2 \pm 0.04$ & $0.4 \pm 0.2$ & $2.3 \pm 0.2$ & $4.0 \pm 0.6$ & $\mathrm{ND}$ & $\mathrm{ND}$ \\
$\mathbf{U C P 2}$ & $1.0 \pm 0.2$ & $0.4 \pm 0.1$ & $0.2 \pm 0.1$ & $13.9 \pm 0.8^{* * *}$ & $\mathrm{ND}$ & $\mathrm{ND}$ & $0.5 \pm 0.3$ & $3.8 \pm 2.4$ & $4.9 \pm 1.4$ & $\mathrm{ND}$ & $\mathrm{ND}$ \\
Bax/Bcl2 & $5.9 \pm 0.6$ & $7.1 \pm 1.4$ & $7.7 \pm 3.2$ & $3.7 \pm 0.3$ & $10.5 \pm 1.2$ & $1.9 \pm 0.5$ & $1.6 \pm 0.5$ & $22.5 \pm 1.6^{* * *}$ & $17.0 \pm 1.7^{* * *}$ & $0.9 \pm 0.4$ & $1.5 \pm 0.4$ \\
\hline
\end{tabular}

G: Glucose; AE: Alperujo extract; ds: days; ND: No detected. Results are relative to housekeeping gene expression and are expressed as the means SEM. One-way ANOVA, Dunnett's post hoc test: ${ }^{* * *} \mathrm{p}<0.001$.

Cells treated for 3 days with AE produced a significant increase of TRDX expression (Table 1, one way ANOVA, $\mathrm{p}<0.001$ ). The $\mathrm{H}_{2} \mathrm{O}_{2} / \mathrm{AE}$ mixture, 5-day experiment induced a paramount increase in TRDX compared to cells only treated with $\mathrm{H}_{2} \mathrm{O}_{2}$ or treated with the $\mathrm{H}_{2} \mathrm{O}_{2} /$ AE mixture for only 3 days (one way ANOVA, $p$ $<0.01$ and $\mathrm{p}<0.001$, respectively). The transcript decreased in cells pre-incubated with AE and further treated with glucose or $\mathrm{H}_{2} \mathrm{O}_{2}$ (one way ANOVA, $\mathrm{p}<0.01$ ).

In cells cultivated for 5 days with AE, p47phox mRNA expression increased (Table 1, one way ANOVA, $\mathrm{p}<$ 0.001); however, cells cultivated for 5 days with glucose or $\mathrm{H}_{2} \mathrm{O}_{2}$ and $\mathrm{AE}$ treatment did not experience changes in p47phox relative abundance. Pre-incubation with AE and further treatment with glucose or $\mathrm{H}_{2} \mathrm{O}_{2}$ showed a trend of decreasing mRNA relative abundance of p47phox.

The Bax/Bcl-2 ratio did not change in cells treated with glucose or $\mathrm{H}_{2} \mathrm{O}_{2}$ alone or those treated with stressors plus AE for 3 days (Table 1). However, the Bax/Bcl-2 ratio increased in cells incubated for 5 days with $\mathrm{AE}$ and either glucose or $\mathrm{H}_{2} \mathrm{O}_{2}$, (one way ANOVA, $\mathrm{p}<0.001$ ).

\section{Discussion}

Oxidative stress is harmful to $\beta$-cell function. Johansen et al. [11] demonstrated that excessive and/or sustained ROS production affects the function and survival of $\beta$-cells, contributing to diabetes pathogenesis. Alperujo, an antioxidant-rich by-product of olive extraction [6] [27], could protect the $\beta$-cell against oxidative stress. In our research the pancreatic $\beta$-cell line, MIN6, was challenged with two stress conditions, $\mathrm{H} 2 \mathrm{O} 2$ and glucose. The $\mathrm{H}_{2} \mathrm{O}_{2}$ concentration used as the stressor agent decreased cell viability by about $50 \%$, which coincides with the results of $\mathrm{Lu}$ et al. [28]. With respect to the glucose concentration used, some authors have reported using concentrations between 5.6 and $16.7 \mathrm{mM}$ [29] as the stressor agent; however, the MIN6 $\beta$-cells used did not survive at concentrations lower than $25 \mathrm{mM}$ (data not shown). For this reason, cells were exposed to high glucose concentrations to determine their survival capacity. For glucose concentrations above $150 \mathrm{mM}$, cell viability decreased by only $26 \%$. Aqueous alperujo extract, a potential anti-oxidant containing $0.5 \mathrm{~g} / 100 \mathrm{ml}$ of gallic acid equivalent or phenol $(20 \mu \mathrm{M})$ was used. This phenol concentration did not induce changes in MIN6 $\beta$-cells viability.

ROS production for each of the treatment conditions was measured over a 24 hour period, demonstrating that AE had a higher pro-oxidant effect on MIN6 $\beta$-cells than $\mathrm{H}_{2} \mathrm{O}_{2}$ or glucose, which did not differentiate ROS production with respect to the control. This finding parallels the results of Oliveira et al. [29] who measured SOD enzymatic activity in pancreatic islets exposed to glucose (5.5 to $16.7 \mathrm{mM}$ ). They found that when glucose concentrations increased, SOD activity also increased. Also, Lu et al. [28] observed that ROS production with 0.15 $\mathrm{mM} \mathrm{H}_{2} \mathrm{O}_{2}$ exceeded the control more than twice in cells exposed to low glucose concentration (14mM). Likewise, Rebelato et al. [30] established that glucose concentrations above $8.3 \mathrm{mM}$ suppress ROS production in a time-dependent manner, due to pentose-phosphate pathway activation and the consequent formation of NADPH, an important substrate to antioxidant cellular defense. They also confirmed that by inhibiting the enzymatic activity of Glucose-6-phosphate dehydrogenase (G6PDH) the glucose flow stopped, thus increasing ROS production. Perhaps, both increased SOD activity and activation of the pentose-phosphate pathway may explain the ROS production level found in cells challenged with glucose $(100 \mathrm{mM})$ and $\mathrm{H}_{2} \mathrm{O}_{2}(0.15 \mathrm{mM})$ for $24 \mathrm{~h}$. Contrary to previous results, challenging cells with $\mathrm{AE}$ alone or in combination with glucose or $\mathrm{H}_{2} \mathrm{O}_{2}$ produced an increment in ROS production, which suggests that $\mathrm{AE}$ contains an oxidizing component that may mask its antioxi- 
dant activity.

Alburquerque et al. [31] measured metal content in AE. They identified Fe, $\mathrm{Cu}, \mathrm{Mn}$ and $\mathrm{Zn}$ in different concentrations, the highest of which was iron $(614 \mathrm{mg} / \mathrm{K})$. The other compound concentrations ranged from 16 to $21 \mathrm{mg} / \mathrm{K}$. This finding suggests that intra- or extracellular $\mathrm{H}_{2} \mathrm{O}_{2}$ would react with the iron present in the $\mathrm{AE}$ and generate hydroxyl radicals that are highly reactive and detectable [14]. Besides, Babich et al. [32] discovered that some natural anti-oxidants such as green tea, black tea, apple extract, and granate extract, in vitro are pro-oxidants depending on the culture medium used. DMEM medium, compared to RPMI 1640 and McCoy media, generates high levels of $\mathrm{H}_{2} \mathrm{O}_{2}$ in the presence of extracts rich in polyphenols. At alkaline $\mathrm{pH}$, polyphenol auto-oxidation occurs which induces an increase in ROS production. Compounds in the medium, such as inorganic salts, vitamins, and amino acids, also contribute to ROS production. To determine if iron would exercise a pro-oxidant role, we quantified Fe content in AE and MIN6 $\beta$-cells after 5 days of challenging the cells in different culture conditions. The Fe content in $\mathrm{AE}, 600 \mathrm{mg} / \mathrm{K}$, is concordant with the levels reported by Alburquerque et al. [31]. There is a close relationship between iron metabolism and glucose levels with oxidative stress [33]. In our study we observed that cells challenged with AE, compound with elevated iron content, had an increased intracellular iron concentration, but also the cells with high glucose in the medium, demonstrating that glucose could stimulate the iron entrance in the cell. However, although both conditions had high intracellular iron the ROS production was higher in $\mathrm{AE}$ challenging, suggesting that $\mathrm{AE}$ together with iron could be more pro-oxidant that iron lonely.

In MIN6 $\beta$-cells cultured with glucose, $\mathrm{AE}$ tends to increase the Bax/Bcl-2 ratio, indicating some degree of cellular apoptosis. This process leads to a decrease in cell mass and therefore a decrease in insulin releasing capacity; however, insulin secretion was not affected in these conditions. A compensatory mechanism could be elucidated by the findings of Hisanaga et al. [34], who revealed that an insulin-induced, calcium-permeable channel—Transient Receptor Potential cation channel, subfamily V, member 2 (TRPV2)—exists in certain tissues (neurons, neuroendocrine cells in the gastrointestinal tract, macrophages, and $\beta$-cells). Insulin secretion, from MIN6 $\beta$-cells cultured with glucose $(25 \mathrm{mM})$, stimulates the synthesis, translocation, and insertion of TRPV2 into the cellular membrane. This facilitates the entry of calcium into the cells, stimulating more insulin secretion into the extracellular space; this mechanism described in MIN6 could explain these finding in insulin secretion. The Bax/Bcl-2 ratio tended to decrease in MIN6 $\beta$-cells pre-incubated with $\mathrm{AE}$, thereby preserving the cell mass. This observation, together with the compensatory mechanism previously described, could explain the increased insulin secretion in these cells.

mRNA relative abundance of UCP-2 and TRDX increased in cells incubated with AE for 3 days. Due to increased antioxidant activity, the Bax/Bcl-2 ratio did not change. As mentioned above, a compensatory mechanism would help sustain insulin secretion despite increasing UCP-2 under these conditions. Furthermore, the challenge lasting more than 3 days with AE tended to decrease MIN6 $\beta$-cell glucose uptake. Johnston et al. [35] demonstrated that certain dietary polyphenols decrease Caco-2 cell glucose uptake, through non-competitive inhibition of GLUT-2 transporters. This finding was confirmed by Kwon et al. [36] and Song et al. [37]. In this study, despite the decreased glucose uptake, there was a rise in p47phox mRNA expression that reflects the pro-oxidant nature of the AE. Despite this rise, the Bax/Bcl-2 ratio was not altered.

The 3-day glucose plus AE condition had a synergistic effect on the intracellular Fe concentration. This increment may have generated oxidative stress, which then triggered a slight increase in Bax/Bcl-2 ratio. The decreased cell mass, due to mitochondrial compromise during apoptosis, could explain the decreased mRNA relative abundance of UCP-2 [20].

The $\mathrm{H}_{2} \mathrm{O}_{2}$ challenge decreased glucose uptake, had no effects on mRNA relative abundance of UCP-2, TRDX, or p47phox, and had a slightly increased the $\mathrm{Bax} / \mathrm{Bcl}-2$ ratio. These results, contradictory to what was expected, have also been reported by Lu et al. [28], who showed that $\mathrm{H}_{2} \mathrm{O}_{2}(0.15 \mathrm{mM})$ decreases SOD, CAT and GSH-Px enzymatic activity, indicating antioxidant defense deregulation in MIN6 $\beta$-cells. Therefore, as expected under the 5-day $\mathrm{H}_{2} \mathrm{O}_{2}$ challenge, there was a tendency towards apoptosis, which the substantial increase in the $\mathrm{Bax} / \mathrm{Bcl}-2$ ratio reflected. When MIN6 $\beta$-cells were pre-incubated with $\mathrm{AE}$ and subsequently challenged with glucose or $\mathrm{H}_{2} \mathrm{O}_{2}$, an increase in the intracellular iron concentration was observed.

Increased intracellular Fe levels in cells challenged with the $\mathrm{AE} / \mathrm{H}_{2} \mathrm{O}_{2}$ mix constitutes an unexpected finding. Also observed, the AE/glucose mix challenge increased glucose uptake a considerable amount. This may be due to an acute effect of glucose load in the culture, since the cells were exposed to AE plus $25 \mathrm{mM}$ glucose for 4 days, and as stated above, AE does not affect glucose uptake. However, the treatment with glucose (100 mM) 24 
hours before the assay probably increased its uptake. mRNA relative abundance of the studied genes and the Bax/Bcl-2 ratio had a tendency to decrease.

\section{Conclusion}

In summary, alperujo extract behaves as a pro-oxidant in the culture conditions. However, despite its nature, $\mathrm{AE}$ tends to protect pancreatic $\beta$-cells against apoptosis, when the cells are pre-incubated with the alperujo, thereby improving insulin secretion.

\section{Acknowledgements}

This research was conducted with support from team of Micronutrient Laboratory, Institute of Nutrition and Food Technology (INTA), in charge of Dr. Miguel Arredondo, highlighting the unconditional support of Dr. Monica Andrews during throughout the development of this research funded by Fondecyt to M. Arredondo (No. 1110080). César González was a master student from the Biomedical Sciences Program, University of Talca.

\section{References}

[1] Tuck, K.L. and Hayball, P.J. (2002) Major Phenolic Compounds in Olive Oil: Metabolism and Health Effects. The Journal of Nutritional Biochemistry, 13, 636-644. http://dx.doi.org/10.1016/S0955-2863(02)00229-2

[2] Aruoma, O.I. (2003) Methodological Considerations for Characterizing Potential Antioxidant Actions of Bioactive Components in Plant Foods. Mutation Research, 523-524, 9-20. http://dx.doi.org/10.1016/S0027-5107(02)00317-2

[3] Perez-Jimenez, F., Alvarez de Cienfuegos, G., Badimon, L., Barja, G., et al. (2005) International Conference on the Healthy Effect of Virgin Olive Oil. European Journal of Clinical Investigation, 35, 421-424.

[4] Fernández-Bolaños, G.J., Guillén, R., Jiménez, A., Rodríguez, R. and Rodríguez, G. (2006) Extraction of Interesting Organic Compounds from Olive Oil Waste. Grasas y Aceites, 57, 95-106.

[5] Tripoli, E., Giammanco, M., Tabacchi, G., Di Majo, D., et al. (2005) The Phenolic Compounds of Olive Oil: Structure, Biological Activity and Beneficial Effects on Human Health. Nutrition Research Reviews, 18, 98-112. http://dx.doi.org/10.1079/NRR200495

[6] Lesage-Meessen, L., Navarro, D., Maunier, S., Sigoillot, J.C., et al. (2001) Simple Phenolic Content in Olive Oil Residues as a Function of Extraction Systems. Food Chemistry, 75, 501-507. http://dx.doi.org/10.1016/S0308-8146(01)00227-8

[7] Robertson, R.P., Harmon, J., Tran, P.O., Tanaka, Y. and Takahashi, H. (2003) Glucose Toxicity in $\beta$-Cells: Type 2 Diabetes, Good Radicals Gone Bad, and the Glutathione Connection. Diabetes, 52, 581-587. http://dx.doi.org/10.2337/diabetes.52.3.581

[8] Waris, G. and Ahsan, H. (2006) Reactive Oxygen Species: Role in the Development of Cancer and Various Chronic Conditions. Journal of Carcinogenesis, 5, 14. http://dx.doi.org/10.1186/1477-3163-5-14

[9] Robertson, P. and Harmon, J.S. (2007) Pancreatic Islet Beta-Cell and Oxidative Stress: The Importance of Glutathione Peroxidase. FEBS Letters, 581, 3743-3748. http://dx.doi.org/10.1016/j.febslet.2007.03.087

[10] Chang, Y.C. and Chuang, L.M. (2010) The Role of Oxidative Stress in the Pathogenesis of Type 2 Diabetes: From Molecular Mechanism to Clinical Implication. American Journal of Translational Research, 2, 316-331.

[11] Johansen, J.S., Harris, A.K., Rychly, D.J. and Ergul, A. (2005) Oxidative Stress and the Use of Antioxidants in Diabetes: Linking Basic Science to Clinical Practice. Cardiovascular Diabetology, 4, 5. http://dx.doi.org/10.1186/1475-2840-4-5

[12] Drews, G., Krippeit-Drews, P. and Dufer, M. (2010) Oxidative Stress and Beta-Cell Dysfunction. Pflügers Archiv, 460, 703-718. http://dx.doi.org/10.1007/s00424-010-0862-9

[13] Prentki, M. and Nolan, C.J. (2006) Islet Beta Cell Failure in Type 2 Diabetes. Journal of Clinical Investigation, 116, 1802-1812. http://dx.doi.org/10.1172/JCI29103

[14] Ma, Z.A., Zhao, Z. and Turk, J. (2012) Mitochondrial Dysfunction and B-Cell Failure in Type 2 Diabetes Mellitus. Experimental Diabetes Research, 2012, Article ID: 703538. doi:10.1155/2012/ 70353811.

[15] Maechler, P. and Wollheim, C.B. (2001) Mitochondrial Function in Normal and Diabetic Beta-Cells. Nature, 414, 807812. http://dx.doi.org/10.1038/414807a

[16] Porterfield, D.M., Corkey, R.F., Sanger, R.H., Tornheim, K., et al. (2000) Oxygen Consumption Oscillates in Single Clonal Pancreatic Beta-Cells (HIT). Diabetes, 49, 1511-1516. http://dx.doi.org/10.2337/diabetes.49.9.1511

[17] Krauss, S., Zhang, C.Y. and Lowell, B.B. (2005) The Mitochondrial Uncoupling-Protein Homologues. Nature Reviews 
Molecular Cell Biology, 6, 248-261. http://dx.doi.org/10.1038/nrm1592

[18] Patane, G., Anello, M., Piro, S., Vigneri, R., et al. (2002) Role of ATP Production and Uncoupling Protein-2 in the Insulin Secretory Defect Induced by Chronic Exposure to High Glucose or Free Fatty Acids and Effects of Peroxisome Proliferator-Activated Receptor-Gamma Inhibition. Diabetes, 51, 2749-2756.

http://dx.doi.org/10.2337/diabetes.51.9.2749

[19] Newsholme, P., Morgan, D., Rebelato, E., Oliveira-Emilio, H.C., et al. (2009) Insights into the Critical Role of NADPH Oxidase(s) in the Normal and Dysregulated Pancreatic Beta Cell. Diabetologia, 52, 2489-2498. http://dx.doi.org/10.1007/s00125-009-1536-Z

[20] Orrenius, S. and Zhivotovsky, B. (2005) Cardiolipin Oxidation Sets Cytochrome c Free. Nature Chemical Biology, 1, 188-189. http://dx.doi.org/10.1038/nchembio0905-188

[21] Newsholme, P., Haber, E.P., Hirabara, S.M., Rebelato, E.L., et al. (2007) Diabetes Associated Cell Stress and Dysfunction: Role of Mitochondrial and Non-Mitochondrial ROS Production and Activity. The Journal of Physiology, 583, 9-24. http://dx.doi.org/10.1113/jphysiol.2007.135871

[22] Bindoli, A., Fukuto, J.M. and Forman, H.J. (2008) Thiol Chemistry in Peroxidase Catalysis and Redox Signaling. Antioxidants Redox Signaling, 10, 1549-1564. http://dx.doi.org/10.1089/ars.2008.2063

[23] Monari, M., Sanchez, G., Cadiz, I., Mera, S. and Castaneda, P. (1993) A Simple Sensitive and Inexpensive Micro Method for the High Performance Liquid Chromatographic Determination of Total and Free Valproic Acid in Human Plasma and Serum. Giornale Italiano Di Chimica Clinica, 17, 353-360.

[24] Singleton, V.L. and Rossi, J.A. (1965) Colorimetry of Total Phenolics with Phosphomolybdic-Phosphotungstic Acid Reagents. American Journal of Enology and Viticulture, 16, 144-158.

[25] Pfaffl, M.W. (2001) A New Mathematical Model for Relative Quantification in Real-Time RT-PCR. Nucleic Acids Research, 29, Article ID: e45. http://dx.doi.org/10.1093/nar/29.9.e45

[26] Yamamoto, N., Ueda, M., Sato, T., Kawasaki, K., Sawada, K., Kawabata, K. and Ashida, H. (2011) UNIT 12.14 Measurement of Glucose Uptake in Cultured Cells. In: Enna, S.J., Eds., Current Protocols in Pharmacology, Chapter 12, 11-22. http://dx.doi.org/10.1002/0471141755.ph1214s55

[27] Galli, C. and Visioli, F. (1999) Antioxidant and Other Activities of Phenolic in Olives/Olive Oil, Typical Components of the Mediterranean Diet. Lipids, 34, S23-S26. http://dx.doi.org/10.1007/BF02562224

[28] Lu, X.Y., Guo, H. and Zhang, Y.L. (2012) Protective Effects of Sulfated Chitooligosaccharides against Hydrogen Peroxide-Induced Damage in MIN6 Cells. International Journal of Biological Macromolecules, 50, 50-58. http://dx.doi.org/10.1016/j.ijbiomac.2011.09.020

[29] Oliveira, H.R., Curi, R. and Carpinelli, A.R. (1999) Glucose Induces an Acute Increase of Superoxide Dismutase Activity in Incubated Rat Pancreatic Islets. American Journal of Physiology, 276, C507-C510.

[30] Rebelato, E., Abdulkader, F., Curi, R. and Carpinelli, A.R. (2011) Control of the Intracellular Redox State by Glucose Participates in the Insulin Secretion Mechanism. PLoS ONE, 6, Article ID: e24507. http://dx.doi.org/10.1371/journal.pone.0024507

[31] Alburquerque, J.A., Gonzalvez, J., Garcia, D. and Cegarra, J. (2004) Agrochemical Characterisation of “Alperujo”, a Solid By-Product of the Two-Phase Centrifugation Method for Olive Oil Extraction. Bioresource Technology, 91, 195200. http://dx.doi.org/10.1016/S0960-8524(03)00177-9

[32] Babich, H., Schuck, A.G., Weisburg, J.H. and Zuckerbraun, H.L. (2011) Research Strategies in the Study of the Pro-Oxidant Nature of Polyphenol Nutraceuticals. Journal of Toxicology, 2011, Article ID: 467305. http://dx.doi.org/10.1155/2011/467305

[33] Fernandez-Real, J.M., Lopez-Bermejo, A. and Ricart, W. (2002) Cross-Talk between Iron Metabolism and Diabetes. Diabetes, 51, 2348-2354. http://dx.doi.org/10.2337/diabetes.51.8.2348

[34] Hisanaga, E., Nagasawa, M., Ueki, K., Kulkarni, R.N., Mori, M. and Kojima, I. (2009) Regulation of Calcium-Permeable TRPV2 Channel by Insulin in Pancreatic $\beta$-Cells. Diabetes, 58, 174-184. http://dx.doi.org/10.2337/db08-0862

[35] Johnston, K., Sharp, P., Clifford, M. and Morgan, L. (2005) Dietary Polyphenols Decrease Glucose Uptake by Human Intestinal Caco-2 Cells. FEBS Letters, 579, 1653-1657. http://dx.doi.org/10.1016/j.febslet.2004.12.099

[36] Kwon, O., Eck, P., Chen, S., Corpe, C.P., Lee, J.H., Kruhlak, M. and Levine, M. (2007) Inhibition of the Intestinal Glucose Transporter GLUT 2 by Flavonoids. FASEB Journal, 21, 366-377. http://dx.doi.org/10.1096/fj.06-6620com

[37] Song, J., Kwon, O., Chen, S., Daruwala, R., et al. (2002) Flavonoid Inhibition of Sodium-Dependent Vitamin C Transporter 1 (SVCT1) and Glucose Transporter Isoform 2 (GLUT2), Intestinal Transporters for Vitamin C and Glucose. Journal of Biological Chemistry, 277, 15252-15260. http://dx.doi.org/10.1074/jbc.M110496200 
Scientific Research Publishing (SCIRP) is one of the largest Open Access journal publishers. It is currently publishing more than 200 open access, online, peer-reviewed journals covering a wide range of academic disciplines. SCIRP serves the worldwide academic communities and contributes to the progress and application of science with its publication.

Other selected journals from SCIRP are listed as below. Submit your manuscript to us via either submit@scirp.org or Online Submission Portal.
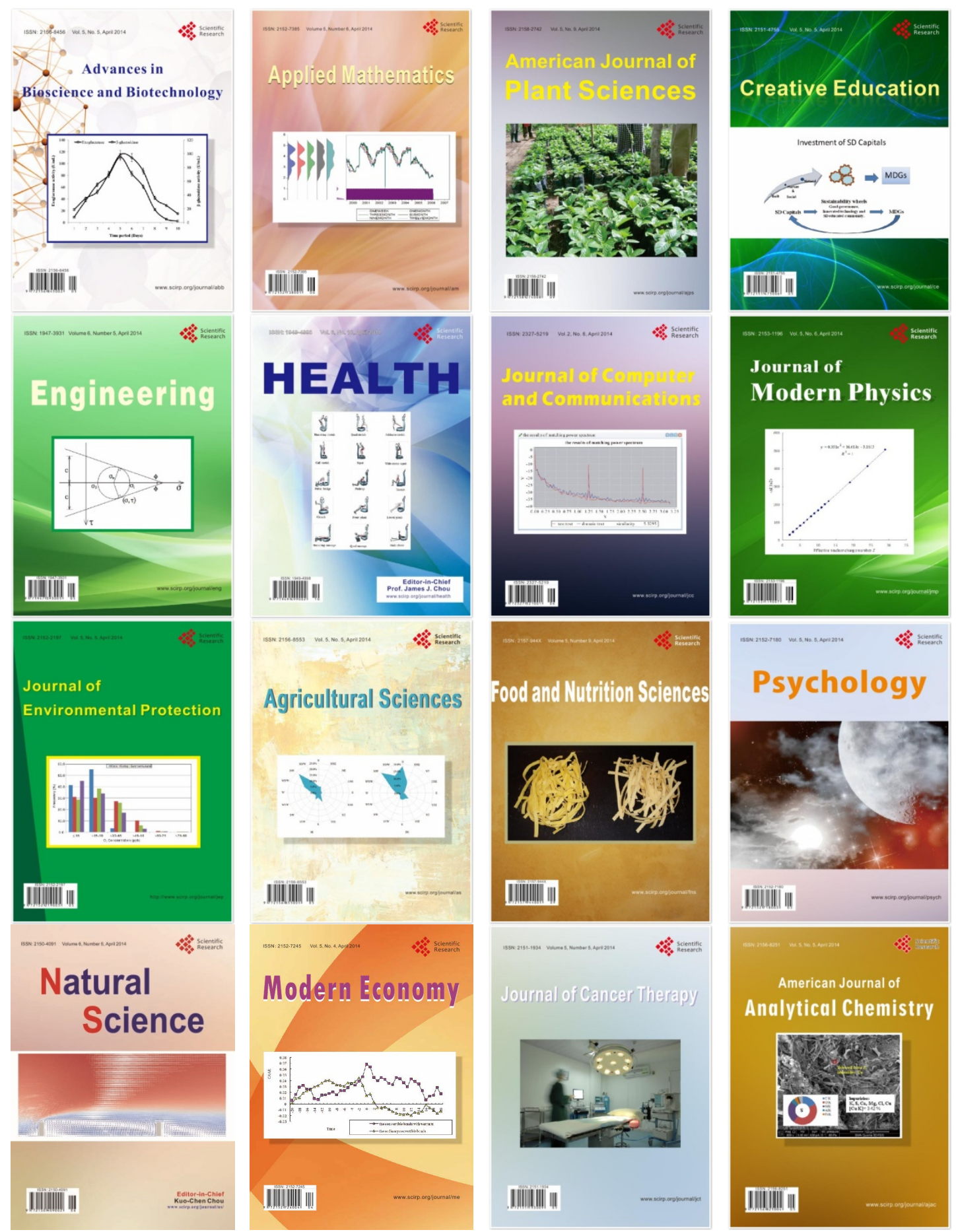